\title{
Effect of Gamma Irradiation on Seed Germination and Seedling Vigour of Mungbean [Vigna radiata (L.)]
}

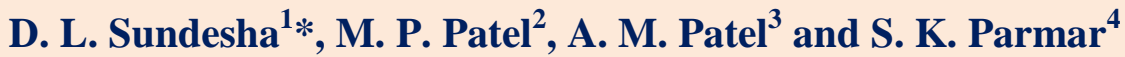

${ }^{1}$ College of Horticulture, S.D. Agricultural University, Sardarkrushinagar-385 506, India

${ }^{2}$ Department of Genetics and Plant Breeding, C. P. College of Agriculture, S. D. Agricultural University, Sardarkrushinagar-385 506, India

${ }^{3}$ Seed-Spices Research Station, S. D. Agricultural University, Jagudan-382 710, India

${ }^{4}$ Pearl Millet Research station, Junagadh Agricultural University, Jamnagar- 361 006, India

*Corresponding author

\begin{tabular}{|c|}
\hline Keywords \\
\hline $\begin{array}{l}\text { Mungbean, Gamma } \\
\text { rays, LD50, } \\
\text { Seedling vigour }\end{array}$ \\
\hline Article Info \\
\hline $\begin{array}{l}\text { Accepted: } \\
\text { 07 September } 2019 \\
\text { Available Online: } \\
10 \text { October } 2019\end{array}$ \\
\hline
\end{tabular}

The pure, healthy and dry seeds of four mungbean varieties i.e., Meha, $\mathrm{K}$ 851 , GM 3 and GM 4 were irradiated with different doses of gamma rays (400, 500 and $600 \mathrm{~Gy}$ ) for study the effect on seed germination and seedling vigour such as germination per cent, shoot length $(\mathrm{cm})$, root length $(\mathrm{cm})$, fresh weight $(\mathrm{g})$ and dry weight $(\mathrm{g})$. For $\mathrm{LD}_{50}$ recorded near to the 600 Gy gamma rays as per survival per cent in the all four mungbean varieties. The GM 4 was observed more sensitive, whereas, Meha was recorded more resistance for most of all traits. The present results clearly indicated that different doses of gamma rays can be effectively utilized to create variability for different quantitative characters in all the four varieties.

\section{Introduction}

Mungbean [Vigna radiata (L.) Wilczek] is the most important pulse crop in India. In the traditional vegetarian diet of Indian population, pulses occupy second place next to cereal and is the main source of protein, ranking after chickpea and pigeonpea. Mungbean, an important seed legume, is a short duration crop and plays vital role in meeting the quantitative and qualitative requirement of food and protein throughout the world. Mungbean provide 24 per cent protein and the seeds are considered to be easily digestible (Chauhan and William, 2018). It also provides nutritional fodder to the cattle and improves the soil fertility through atmospheric nitrogen fixation with the help of Rhizobium species. Plant breeders always look for large and diverse gene pool of variability as it is a prerequisite for success in any breeding programme. In mungbean, natural 
variability is limited and hybridization is little difficult due to cleistogamous and small flower structure. Therefore, induced mutation technique was followed to create genetic variability by artificial means.

\section{Materials and Methods}

The true pure seeds of four mungbean varieties viz., Meha, K 851, GM 3 and GM 4 were procured from the Pulse Research Station, SDAU, Sardarkrushinagar. Pure, healthy and mature seeds of the selected varieties were exposed to different doses of gamma rays (400 Gy, $500 \mathrm{~Gy}$ and 600 Gy) with an intensity of 18 Gy per minute at Bhabha Atomic Research Centre (BARC), Trombay. Seeds not irradiated to gamma ray which were concern as a control. In each treatment, In laboratory condition, 25 seeds were sown treatment wise in the cement pipe structure with proper plant as well as row spacing during summer-2014. Germination of seeds were carefully examined everyday and the emergence of cotyledonary leaf was taken as the induction of germination, germinated seeds of each treatment were counted on eighth day after sowing and germination percentage was calculated. Fifteen days of after sowing, shoot and length were measured in centimeter and fresh weight $(\mathrm{g})$ was recorded, seedlings were put in oven at constant $50^{\circ} \mathrm{C}$ temperature for 48 hours and after these seedling weight was recorded as dry weight $(\mathrm{g})$ and total number of seedlings survived were counted after fifteen day of sowing and plant survival percentage were calculated in the $\mathbf{M}_{1}$ generation.

\section{Results and Discussion}

In present study, the highest mean germination per cent $(88,96,96$ and 92) and survival per cent $(88,96,96$ and 92) was observed in control treatment, whereas lowest mean germination per cent $(56,68,68$ and 60) and survival per cent (48, 48, 60 and 40) was recorded at $600 \mathrm{~Gy}$ in four varieties Meha, $\mathrm{K}$ 851, GM 3 and GM 4, respectively (Table 1). Mean germination per cent was reduced in all four varieties with the increase in gamma rays doses. The perusal of the results suggested that the dose of gamma rays was increased when, the germination per cent and survival per cent were reduced. Differential genotypic sensitivity to different mutagen doses within a species have also been reported by several workers viz., Balai and Krishna, 2009; Kumar et al., 2010; Sagade and Apparao, 2011, Singh and Singh, 2013 and Hemavathy, 2015 in Vigna radiata. Cherry and Hageman (1961) opined that impairment of mitosis or, virtual elimination of cell division in the meristematic zone during germination in irradiated seeds with higher doses led to seed lethality. However, Selim et al., (1974) reported that reduction in germination due to higher exposure to radiation was due to production of active radicals. Sato and Gaul (1967) reported that seedling injury led to slow growth culminating in early mortality. Chromosomal aberrations as impacted by irradiation caused reduction in fertility and enhancement of physiological disorders causing seedling injury, slow growth and ultimately early mortality (Mehetre et al., 1994; Avinash and Tewari, 1998). Higher degree of damage incited by irradiations to chromosomal materials also results in inhibition of growth hormones. All these factors cumulatively may be attributed as the reason for reduction of plant survival.

Highest shoot length $(6.90,6.71,7.06$ and $7.05 \mathrm{~cm})$, root length $(7.40,7.35,7.54$ and $7.41 \mathrm{~cm})$, fresh weight $(1.05,1.09,1.15$ and $1.13 \mathrm{~g})$, dry weight $(0.52,0.55,0.62$ and 0.59 g) were recorded under control treatment in Meha, K 851, GM 3 and GM 4, respectively.

Mean shoot and root length as well as mean of fresh and dry weight were declined in all four varieties with increase in gamma rays dose. 


\begin{tabular}{|c|c|c|c|c|c|c|c|c|}
\hline \multirow[t]{2}{*}{ Varieties } & \multirow{2}{*}{$\begin{array}{c}\text { Treatments } \\
\text { Gamma }\end{array}$} & \multirow{2}{*}{$\begin{array}{l}\text { Number } \\
\text { of seeds } \\
\text { sown }\end{array}$} & \multicolumn{3}{|c|}{ Seed germination } & \multicolumn{3}{|c|}{ Per cent seed survival } \\
\hline & & & $\begin{array}{l}\text { Number of } \\
\text { seeds } \\
\text { germinated }\end{array}$ & $\begin{array}{l}\text { Mean } \\
\text { germination } \\
\text { in per cent }\end{array}$ & $\begin{array}{c}\text { Reduction } \\
\text { over } \\
\text { control } \\
\text { per cent }\end{array}$ & $\begin{array}{c}\text { Number of } \\
\text { seeds } \\
\text { survival }\end{array}$ & $\begin{array}{c}\text { Mean } \\
\text { survival in } \\
\text { per cent }\end{array}$ & $\begin{array}{c}\text { Reduction } \\
\text { over } \\
\text { control } \\
\text { per cent }\end{array}$ \\
\hline \multirow[t]{4}{*}{ Meha } & Control & 25 & 22 & 88 & - & 22 & 88 & - \\
\hline & $400 \mathrm{~Gy}$ & 25 & 20 & 80 & 09.00 & 17 & 68 & 22.73 \\
\hline & $500 \mathrm{~Gy}$ & 25 & 17 & 68 & 22.73 & 16 & 64 & 27.27 \\
\hline & $600 \mathrm{~Gy}$ & 25 & 14 & 56 & 36.36 & 12 & 48 & 45.45 \\
\hline \multirow[t]{4}{*}{ K 851} & Control & 25 & 24 & 96 & - & 24 & 96 & - \\
\hline & $400 \mathrm{~Gy}$ & 25 & 22 & 88 & 08.33 & 21 & 84 & 12.50 \\
\hline & $500 \mathrm{~Gy}$ & 25 & 18 & 72 & 25.00 & 18 & 72 & 25.00 \\
\hline & $600 \mathrm{~Gy}$ & 25 & 17 & 68 & 29.17 & 12 & 48 & 50.00 \\
\hline \multirow[t]{4}{*}{ GM 3} & Control & 25 & 24 & 96 & - & 24 & 96 & - \\
\hline & $400 \mathrm{~Gy}$ & 25 & 23 & 92 & 04.17 & 20 & 80 & 16.67 \\
\hline & $500 \mathrm{~Gy}$ & 25 & 19 & 76 & 20.83 & 18 & 72 & 25.00 \\
\hline & $600 \mathrm{~Gy}$ & 25 & 17 & 68 & 29.17 & 15 & 60 & 37.50 \\
\hline \multirow[t]{4}{*}{ GM 4} & Control & 25 & 23 & 92 & - & 23 & 92 & - \\
\hline & $400 \mathrm{~Gy}$ & 25 & 22 & 88 & 04.35 & 21 & 84 & 08.70 \\
\hline & $500 \mathrm{~Gy}$ & 25 & 20 & 80 & 13.04 & 20 & 80 & 13.04 \\
\hline & $600 \mathrm{~Gy}$ & 25 & 15 & 60 & 34.78 & 10 & 40 & 56.52 \\
\hline
\end{tabular}




\begin{tabular}{|c|c|c|c|c|c|c|c|c|c|}
\hline \multirow[t]{2}{*}{ Varieties } & \multirow[t]{2}{*}{ Treatments } & \multicolumn{2}{|c|}{ Shoot length $(\mathrm{cm})$} & \multicolumn{2}{|c|}{ Root length (cm) } & \multicolumn{2}{|c|}{ Fresh weight (g) } & \multicolumn{2}{|c|}{ Dry weight (g) } \\
\hline & & $\begin{array}{c}\text { Mean } \\
(\mathrm{cm})\end{array}$ & $\begin{array}{l}\text { Per cent } \\
\text { reduction } \\
\text { over } \\
\text { control }\end{array}$ & $\begin{array}{c}\text { Mean } \\
(\mathrm{cm})\end{array}$ & $\begin{array}{l}\text { Per cent } \\
\text { reduction } \\
\text { over } \\
\text { control }\end{array}$ & $\begin{array}{c}\text { Mean } \\
(\mathrm{g})\end{array}$ & $\begin{array}{l}\text { Per cent } \\
\text { reduction } \\
\text { over } \\
\text { control }\end{array}$ & $\begin{array}{c}\text { Mean } \\
(\mathrm{g})\end{array}$ & $\begin{array}{c}\text { Per cent } \\
\text { reduction } \\
\text { over } \\
\text { control }\end{array}$ \\
\hline \multirow[t]{4}{*}{ Meha } & Control & 6.90 & - & 7.40 & - & 1.05 & - & 0.52 & - \\
\hline & $400 \mathrm{~Gy}$ & 4.15 & 39.86 & 4.90 & 33.78 & 1.03 & 02.05 & 0.49 & 05.78 \\
\hline & $500 \mathrm{~Gy}$ & 3.83 & 44.49 & 4.50 & 39.19 & 0.99 & 06.14 & 0.51 & 01.36 \\
\hline & $600 \mathrm{~Gy}$ & 3.35 & 51.45 & 3.68 & 50.27 & 0.97 & 07.77 & 0.46 & 11.47 \\
\hline \multirow[t]{4}{*}{ K 851} & Control & 6.71 & - & 7.35 & - & 1.09 & - & 0.55 & - \\
\hline & $400 \mathrm{~Gy}$ & 4.12 & 38.64 & 4.85 & 34.04 & 1.04 & 04.76 & 0.50 & 09.89 \\
\hline & $500 \mathrm{~Gy}$ & 3.75 & 44.14 & 4.40 & 40.13 & 1.00 & 08.55 & 0.52 & 05.23 \\
\hline & $600 \mathrm{~Gy}$ & 3.24 & 51.71 & 3.54 & 51.81 & 0.97 & 10.69 & 0.46 & 15.56 \\
\hline \multirow[t]{4}{*}{ GM 3} & Control & 7.06 & - & 7.54 & - & 1.15 & - & 0.62 & - \\
\hline & $400 \mathrm{~Gy}$ & 4.30 & 39.14 & 5.02 & 33.42 & 1.09 & 05.22 & 0.55 & 11.21 \\
\hline & $500 \mathrm{~Gy}$ & 3.91 & 44.67 & 4.52 & 40.12 & 1.05 & 08.70 & 0.57 & 07.56 \\
\hline & $600 \mathrm{~Gy}$ & 3.37 & 52.31 & 3.73 & 50.58 & 1.03 & 10.43 & 0.52 & 15.83 \\
\hline \multirow[t]{4}{*}{ GM 4} & Control & 7.05 & - & 7.41 & - & 1.13 & - & 0.59 & - \\
\hline & 400 Gy & 4.19 & 40.54 & 5.02 & 32.22 & 1.06 & 06.39 & 0.52 & 12.06 \\
\hline & $500 \mathrm{~Gy}$ & 3.86 & 45.20 & 4.58 & 38.24 & 1.02 & 10.12 & 0.54 & 08.73 \\
\hline & 600 Gy & 3.38 & 52.05 & 3.86 & 47.89 & 1.00 & 11.78 & 0.49 & 17.15 \\
\hline
\end{tabular}


These traits mean values were recorded highest in control, whereas, lowest mean values were recorded at 600 Gy (Table 2). The results suggested that differential response to different doses of gamma rays. The reduction in shoot length and root length were thus more pronounced in higher doses as compared to the lower doses of gamma rays and their respective to untreated control. The varietal response of mutagen was little founded. The reduction in shoot and root length recorded in the flat studies has been attributed to changes in the levels of auxin and ascorbic acid and to physiological and bio-chemical disturbances (Gunkel and Sparrow, 1954 and Singh, 1974) or chromosomal aberrations changes in enzymatic activity and impaired mitosis in the meristematic zone of growing seedlings (Cherry and Hageman, 1961). It might be due to decrease in respiratory quotient in the seedlings obtained from treated seeds. Such chromosomal aberrations caused due to induction of mutation have also been reported by Nandanwar and Patil (2000).

In this study, GM 4 was observed more sensitive, whereas, Meha was recorded more resistance for most of all traits. The results clearly indicated that different doses of gamma rays can be effectively utilized to create variability for different quantitative characters in all the four varieties.

\section{References}

Avinash, C. and Tewari, S.N. (1998). Effect of fast neutrons and gamma radiation on germination, pollen and ovule sterility and leaf variations in mungbean. Acta Botanica Indica. 6: 206-208.

Balai, O.P. and Krishna, K.R. (2009). Efficiency and effectiveness of chemical mutagens in mungbean. Journal of Food Legumes. 22(2): 105108.

Chauhan, Y.S. and Williams, R. (2018).
Physiological and Agronomic Strategies to Increase Mungbean Yield in Climatically Variable Environments of Northern Australia. Agronomy. 8 (6): 1-20.

Cherry, J.H. and Hageman, R.H. (1961). Nucleotide and ribonucleic acid metabolism of corn seedlings. Plant Physiology. 36: 163-168.

Gunkel, J.E. and Sparrow, A.H.(1954). Aberrant growth in plants induced by ionizing radiation. Brookhaven Symposium Biology. 6: 252-279.

Hemavathy, A.T. (2015). Effect of gamma irradiation on seed germination and seedling growth of Vigna radiata (L.) Hepper. International Journal of Advanced Scientific and Technical Research. 2 (5): 155-158.

Kumar, A., Parmhansh, P., Mandal, R.K. and Prasad, R. (2010). Induced mutations in mungbean (Vigna radiata L. Wilczek). Agriculturist. 54 (3/4): 173178.

Mehetre, S.S., Mahajan, C.R. and Dhumal, P.M. (1994). Effects of different doses of gamma irradiation on germinations and survival of soybean. Soybean Genetics News Letter. 21: 101-112.

Nandanwar, R.S. and Patil, A.N. (2000). Meiotic chromosomal aberrations, spectrum and frequency of chlorophyll and macro mutations induced by gamma rays, EMS and hydroxylamine in [Vigna radiata (L.) Wilczek]. DAEBRNS Symposium, Mumbai.: 156165.

Sagade, A.B. and Apparao, B.J. (2011). $\mathbf{M}_{1}$ Generation Studies in Urdbean [Vigna mungo (L.) Hepper]. Asian Journal of Experimental Biological Science. 2 (2): 372-375.

Sato, M. and Gaul, H. (1967). Effect of EMS on the fertility of barley. Radiation Botany. 7: 7-15.

Selim, A.R., Hussein, H.A.S. and El-Shawaf, 
L.L.S. (1974). Journal of Genetical Cytology. 192. Fide: Perspectives in Cytology and Genetics. (Ed. Manna, G.K. and Sinha, U.). Hindasa Publication, New Delhi.: 353-356.

Singh, B.B. (1974). Radiation induced changes in catalase, lipase and ascorbic acid of safflower seeds during germination. Radiation Botany. 14: 195-199.

Singh, K. and Singh, M.N. (2013). Effectiveness and efficiency of Gamma rays and Ethyl Methane Sulphonate (EMS) in mungbean. Journal of Food Legumes. 26 (3 and 4): $25-28$.

\section{How to cite this article:}

Sundesha, D.L., M.P. Patel, A.M. Patel and Parmar, S.K. 2019. Effect of Gamma Irradiation on Seed Germination and Seedling Vigour of Mungbean [Vigna radiata (L.)]. Int.J.Curr.Microbiol.App.Sci. 8(10): 598-603. doi: https://doi.org/10.20546/ijcmas.2019.810.067 